\title{
Diagnóstico da escolarização no Brasil na perspectiva da exclusão escolar
}

ALCEU RAVANELLO FERRARO Universidade Federal do Rio Grande do Sul, Porto Alegre, RS, Brasil

STEVEN DUTT ROSS Universidade Federal do Estado do Rio de Janeiro, Rio de Janeiro, RJ, Brasil

RESUMO

Este artigo é um estudo crítico da perspectiva da exclusão, que ganhou destaque especialmente nos anos de 1980 a 1990 e foi aplicada, tanto na França como no Brasil, em diagnósticos de escolarização, por noções como as de exclusão da escola, exclusão na escola e excluídos do interior. As análises desenvolvidas revelam que, em que pesem as limitações inerentes à noção de exclusão, de poder mais descritivo que explicativo, esta continua prestando-se para dimensionar os desafios ainda postos à universalização da escolarização básica. Com efeito, ressalvados os avanços obtidos desde 1980, o Brasil contava ainda, em 2010, com 3,2 milhões de crianças e adolescentes de 4 a 17 anos fora da escola (excluídos da escola) e outros sete milhões com dois ou mais anos de defasagem nos estudos (de excluídos na escola).

PALAVRAS-CHAVE

escolarização; diagnóstico; exclusão escolar; Brasil. 


\section{DIAGNOSIS OF BASIC SCHOOLING IN BRAZIL IN THE PERSPECTIVE OF SCHOOL EXCLUSION}

\section{ABSTRACT}

This article is a critical study of the perspective of exclusion, which became important especially in the 1980s and 1990s and was applied, both in France and in Brazil, in schooling diagnosis, through notions such as exclusion from the school, exclusion in the school and excluded of the interior (exclus de l'interieur). The analyses developed show that, despite the inherent limitations to the notion of exclusion, with a more descriptive than explanatory power, it is still useful to size the challenges yet imposed on the universalization of basic schooling. Indeed, except for the advances achieved since 1980, Brazil still had, in 2010, 3.2 million children and adolescents, aged 4 to 17 years old out of school (excluded from the school), and another seven millions lagging two or more years behind in their studies (excluded in the school).

KEYWORDS

schooling; diagnosis; school exclusion; Brazil.

\section{DIAGNÓSTICO DE LA ESCOLARIZACIÓN EN BRASIL EN LA PERSPECTIVA DE LA EXCLUSIÓN ESCOLAR}

\section{RESUMEN}

Este artículo es un estudio crítico de la perspectiva de la exclusión, que ha tenido realzo en los años 1980 y 1990 e ha sido aplicada, tanto en Francia como en Brasil, para el diagnóstico de la escolarización, través nociones como las de exclusión de la escuela, exclusión en la escuela y excluidos del interior. Los análisis desarrollados muestran que, a despecho de las limitaciones propias de la noción de exclusión, de poder más descriptivo que explicativo, ésta sigue útil para dimensionar los desafíos en la realización del objetivo de la universalización de la escolarización básica. Con efecto, no olvidados los avanzos obtenidos desde los años 1980, el Brasil tenía todavía, en 2010, 3,2 millones de chicos y adolescentes de 4 a 17 años fuera de la escuela (excluidos de la escuela) y otros siete millones con dos o más años de atraso escolar (excluidos en la escuela).

PALABRAS CLAVE

escolarización; diagnóstico; exclusión escolar; Brasil. 
O presente artigo é resultado da parceria de dois pesquisadores: um cientista social e um estatístico, apresentando os primeiros resultados de projeto de pesquisa ${ }^{1}$ que tem como objetivo estabelecer um confronto entre diferentes perspectivas teóricas de diagnóstico da escolarização. Tais perspectivas são principalmente quatro:

1. da exclusão escolar;

2. das desigualdades educacionais;

3. da dívida educacional; e

4. do fracasso escolar - perspectivas estas postas geralmente na forma das antinomias inclusão-exclusão, igualdade-desigualdade, direito-dívida, sucesso-fracasso.

Concretamente, o que os autores deste artigo se propuseram foi desenvolver um diagnóstico atualizado da escolarização básica no Brasil na perspectiva da exclusão escolar, esta entendida no sentido estrito e restrito que se irá atribuir ao referido termo.

Mas há uma questão de fundo, que pode ser assim formulada: Faz ainda sentido falar em exclusão escolar no Brasil, depois de duas décadas (anos 1990 e 2000) marcadas por forte movimento de ampliação do acesso de crianças, adolescentes e jovens à escola? Para começar, e contrariando o coro de vozes que, de longa data, vem dando como já realizada, ou quase, a universalização do acesso à escola no Brasil (Castro, 1989; Fletcher, 1985; Fletcher e Castro, 1986; Fletcher e Ribeiro, 1987; Klein e Ribeiro, 1991; Ribeiro, 1991, entre outros), vale lembrar aqui a enfática denúncia feita logo no início de obra publicada quando se escrevia este artigo: "Mais de 3,8 milhões de crianças e adolescentes de 4 a 17 anos de idade estavam fora da escola no Brasil em 2010, segundo o Censo Demográfico"(UNICEF, 2014, p. 8). Com efeito, o último censo demográfico acusa um total de 3.848 .398 crianças e adolescentes de 4 a 17 anos que não frequentavam escola no Brasil em 2010, concentrados nos dois grupos etários extremos: 30\% (1.154.572) no grupo de $4 \mathrm{a}$ 5 anos, correspondente à educação pré-escolar, e 44,9\% (1.727.522) no grupo de 15 a 17 anos, correspondente ao ensino médio (IBGE, 2010).

Tais números confirmam que continua havendo, no Brasil, crianças e adolescentes fora da escola, problema a que se soma a grande quantidade deles que, em decorrência de sucessivas reprovações e repetências, apresentam forte defasagem nos estudos.

Porém a questão a enfrentar logo de início é a de discernir os limites e o eventual alcance da expressão exclusão escolar no diagnóstico da escolarização.

\section{O SURTO DA EXCLUSÃO}

No início dos anos de 1990, Donzelot e Roman² (1991, p. 5) sustentavam que o tema da exclusão suscitara debates já no início da década de 1970, mas então se referindo aos esquecidos do crescimento, como em Les exclus (Os excluídos), de

1 Projeto de pesquisa em desenvolvimento, contando com apoio do Conselho Nacional de Desenvolvimento Científico e Tecnológico (CNPq).

2 As traduções do francês e do espanhol são de responsabilidade dos autores deste artigo. 
René Lenoir (1974); apenas a partir do início dos anos de 1980 esse termo teria passado a significar "não mais uma omissão involuntária, mas uma solução deliberada", a saber: "Para modernizar, é necessário reduzir os efetivos, só conservando os indivíduos capazes de servir às mutações tecnológicas e rejeitando os outros, todos os outros [...]" (Donzelot e Roman, 1991, p. 5).

No mesmo ano do texto de Donzelot e Roman, aparecia na revista Esprit o artigo Face à l'exclusion (Face à exclusão), em que Alain Touraine (1991) surpreende com a polêmica tese de que o paradigma de classes sociais teria dado lugar ao paradigma da exclusão, ou seja, de que se teria passado de uma sociedade vertical, habitualmente chamada de sociedade de classes, centrada na perspectiva upperdown, em cima-embaixo, dominantes-dominados, para uma sociedade horizontal, centrada na questão de estar in-out, dentro-fora.

No ano seguinte ao artigo de Touraine, teríamos o artigo Les exclus de l'interieur (Os excluídos do interior), em que Bourdieu e Champagne (1992), sem ignorar os excluídos da escola, se referem aos excluídos que permanecem no interior da escola, em uma situação por eles definida como exclusão potencial ou exclusão adiada.

No mesmo ano, a revista Esprit (1992) publica um número especial intitulado La France de l'exclusion (A França da exclusão). Nela, entre outros temas, Perret (1992) trata dos limites da inclusão pelo trabalho, e J. B. Foucault (1992, p. 47 e 53) inicia seu artigo, Exclusion, inégalités et justice sociale (Exclusão, desigualdades e justiça social), perguntando se desigualdades e exclusões eram da mesma natureza, observando que, àquela altura (de fim do Estado do bem-estar), necessitava-se de "um método para abordar corretamente a questão das desigualdades, isto é, um enfoque capaz de integrar desigualdade e exclusão, numa ótica de coesão social e de sociedade dinâmica" (Foucault, 1992, p. 53).

Naquele momento, a onda da exclusão era tão forte, que a tradução de uma obra alemã de 1975, publicada na França sob o título Les marginaux: femmes, juifs et homosexuels dans la littérature européenne (Os marginais: mulheres, judeus e homossexuais na literatura europeia) (Mayer, 1994), apareceu em livraria no centro do Rio de Janeiro envolta em uma faixa de papel onde se lia: "LES ORIGINES DE L'EXCLUSION" (As origens da exclusão). Toda a obra tratava da marginalidade; mas o que, então, estava na moda e também vendia melhor era a exclusão.

Em 1996, apareceria a volumosa coletânea L'exclusion: l'état des savoirs (A exclusão: o estado do conhecimento), em que o diretor da obra, Paugan (1996, p. 7), inicia observando que, na França, nos últimos dez anos, a exclusão se tornara uma noção familiar, quase banal. Ainda, segundo o autor, em que pesassem as diferenças, a noção de exclusão poderia ser comparada à noção de pauperismo do século XIX (Paugan, 1996, p. 7-8). Convergindo na direção da tese de Touraine, já referida, Schnapper (Paugan, 1996, p. 23) inicia seu texto com a expressão "paradigma da exclusão", dizendo, na sequência, que este se tornara "brutalmente dominante" nos últimos anos, "depois que a luta das classes e das desigualdades tinha dominado os debates políticos e a reflexão sociológica desde o final da Segunda Guerra Mundial”.

Estranhamente, nessa mesma coletânea, Merrien (Paugan, 1996, p. 423) dava o termo exclusão como "criação francesa recente". Van Zanten (Paugan, 1996, p. 281), por sua vez, dizia que, "para se falar de segregação escolar, é necessário ter 
condições de mostrar que a concentração espacial na escola leva à produção de formas específicas de desigualdade ou de exclusão escolares e sociais". O texto de Queiroz (Paugan, 1996, p. 295-310) permite destacar alguns pontos importantes: primeiro, que existia um acordo entre os sociólogos na crítica da ambiguidade do termo exclusão, noção social mais que conceito sociológico; segundo, que, apesar da justeza dessas críticas, os sociólogos continuavam e continuariam usando o termo exclusão; terceiro, que o "problema dos excluídos" estava mal colocado, porque na realidade tratava-se de saber como incluir, porquanto em uma sociedade democrática conservam-se dentro aqueles que não se encaixam em determinada racionalidade, de sorte que, por esse aspecto, todos os excluídos são "excluídos do interior", segundo a expressão de Bourdieu e Champagne (1992), antes aqui já referida. Para Procacci (Paugan, 1996, p. 415), o debate sobre a exclusão se fazia em um vazio teórico que tomava para análise uma simples constatação estatística, que parecia haver renunciado a qualquer reflexão crítica sobre os instrumentos analíticos utilizados e que, finalmente, tratava a exclusão como uma condição em vez de um processo e, dessa forma, separava a pobreza do restante da sociedade. Segundo esse autor, "é o problema da desigualdade, que havia estado no coração da racionalidade econômica moderna da pobreza, que é relegado pelas análises em termos de exclusão social”.

Por fim, já mais para o fim da década de 1990, teríamos a obra La production des exclus: politiques sociales e processus de désocialisation socio-politique (A produção dos excluídos: políticas sociais e processos de dessocialização sociopolítica), que a autora inicia com as seguintes palavras, provocativas e, ao mesmo tempo, desconcertantes: "A exclusão não é nem um conceito sociológico, nem uma noção fluida, mas [uma noção] fundamental para a análise sociológica, mesmo que saturada de senso, de não senso e de contrassenso" (Thomas, 1997, p. 1, grifos do original). A novidade, segundo a autora, estaria no fato de essa categoria da exclusão, que introduziu "um novo vocabulário, uma nova análise e um novo tratamento da pobreza", se haver imposto progressivamente no decorrer dos anos de 1970 a 1990, mas dando continuidade à categoria da pobreza e propondo uma nova forma de problematização da "questão social" da "desclassificação social" (Thomas, 1997, p. 9). Vale destacar as seguintes conclusões presentes nessa obra:

- A exclusão não é um conceito sociológico operatório, mas uma categoria não científica (demi-savante) de avaliação e de ação. [...]

- A exclusão é um novo tipo de categoria de classificação de base política que agrupa indivíduos desclassificados na hierarquia social. [...]

- O vagabundo serve de tipo-ideal e de modelo-contraste à categoria da exclusão. (Thomas, 1997, p. 195-199)

No ano seguinte, na obra Vagabondage et mendicité (Vagabundagem e mendicidade), Damon (1998) sustenta que, justamente no momento em que a atenção e a ação públicas centravam-se sobre a exclusão, reapareciam os debates sobre a mendicidade e a vagabundagem, fenômenos históricos que mereceram a atenção de grande número de pesquisadores. ${ }^{3}$ No dizer do autor, essa noção de exclusão,

3 Sobre isso, pode-se ver: Himmelfarb (1988); Messner (1960); Mollat (1978); Sassier (1990). 
"bem francesa", sob cuja medida eram apreciadas as questões da pobreza, da desigualdade ou da cidadania, reunia "problemas extremamente diferentes sob uma mesma etiqueta”, não permitindo captar claramente os fenômenos que ela buscava designar (Damon, 1998, p. 100). E o autor prossegue em sua crítica:

A exclusão alimenta o debate público de maneira obsessiva. Ela se faz objeto de dossiês, dá lugar a inumeráveis seminários, suscita iniciativas originais e, acima de tudo, os excluídos se tornaram o tema obrigatório do debate político, e isto até à caricatura. (Damon, 1998, p. 101)

No artigo A escola e a exclusão, Dubet (2003, p. 30) sustenta que esse tema não era dos mais simples e que ele remetia a uma série de problemas, tais como:

- o lugar da escola numa estrutura social perpassada pelos mecanismos de exclusão;

- a análise dos mecanismos propriamente escolares que engendram uma segmentação escolar, determinante na formação dos percursos de exclusão;

- as consequências dessa mutação estrutural sobre a natureza das próprias experiências escolares tanto dos professores como dos alunos.

$\mathrm{Na}$ opinião do autor, a exclusão é um indicador de que a escola passou por uma transformação que ultrapassa de longe os casos agudos de exclusão. "O problema da exclusão nos ensina que as relações da escola e da sociedade se transformaram e que a escola perdeu sua "inocência". A própria escola se teria tornado "o agente de uma exclusão específica que transforma a experiência dos alunos e abre uma crise de sentido nos estudos, às vezes até da legitimidade da instituição escolar", de sorte que, decorrido já um século desde a sua formação como "escola republicana", ela nos convida a nos interrogarmos sobre as finalidades da educação. Assim, a exclusão escolar não seria mais que "o resultado 'normal' da extensão de uma escola democrática de massa que afirma ao mesmo tempo a igualdade dos indivíduos e a desigualdade de seus desempenhos", de maneira que, hoje, independentemente de seus princípios e suas ideologias, ela "integra mais e exclui mais que antes [...] e funciona cada vez mais como o mercado, que é, em sua própria lógica, o princípio básico da integração e da exclusão" (Dubet, 2003, p. 43-44).

Sintetizando, pode-se dizer que o ponto alto do tema da exclusão na França ocorreu na década de 1990, entrando pelo novo século adentro, mas já aparecendo algumas críticas a essa onda da exclusão.

\section{A TEMATIZAÇÃO DA EXCLUSÃO ESCOLAR NO BRASIL}

O tema da exclusão ganhou relevo também no Brasil. A atenção volta-se, aqui, principalmente para a repercussão que o assunto teve na área da educação, na qual sua presença já se fazia notar pelo menos desde meados da década de 1980. Assim, por exemplo, em artigo sobre analfabetismo, que trata da produção de novos analfabetos: 
E essa produção de novos analfabetos se faz através da exclusão praticada pelo aparelho escolar. São vítimas dessa exclusão: 1) todos aqueles que são excluídos in limine, os que nem sequer chegam a ser admitidos no processo de alfabetização na idade de escolarização obrigatória; 2) aqueles que, tendo sido admitidos, são posteriormente excluídos do processo; 3 ) aqueles que, ainda dentro do sistema de ensino, estão sendo objeto de exclusão no próprio processo de ensino através da reprovação e repetência e estão sendo assim preparados para a posterior exclusão do processo. A exclusão praticada no processo de alfabetização, através da reprovação e repetência, alimenta, no momento seguinte, através do que eufemisticamente se denomina de evasão escolar, o contingente dos excluídos do processo. (Ferrari, 1985, p. 49).

Mas foi em artigo publicado dois anos mais tarde que o termo exclusão escolar apareceu desdobrado com maior clareza nas categorias exclusão da escola e exclusão na escola: a primeira categoria compreendendo aquelas crianças e adolescentes que nunca ingressaram na escola, mais aquelas que, ainda na faixa de escolarização obrigatória (7 a 14 anos, então), já haviam dela sido excluídos; a segunda categoria tendo a ver diretamente com o próprio processo de alfabetização e escolarização, habitualmente "obscurecida por expressões como baixo rendimento, fracasso escolar, reprovação, recuperação, repetência", sendo que, aqui, "os excluídos ainda estão na escola, ainda em processo de escolarização” (Ferrari, 1987, p. 93). A já referida expressão excluídos do interior, que surgiria alguns anos mais tarde (Bourdieu e Champagne, 1992), parece coincidir com a categoria de excluídos na escola.

A partir do final da década de 1990, multiplicaram-se estudos em duas direções que aqui interessam: uma, de crítica de algumas concepções sobre exclusão; a outra, de análise da exclusão escolar.

No que concerne à crítica a determinadas concepções de exclusão, destacam-se aqui dois pontos. Em primeiro lugar, aquele que se refere à dita novidade de fenômeno denominado exclusão. Para Ribeiro (1999, p. 37), o "estado de exclusão" é tão velho como a humanidade e se refere a diferentes processos de segregação, tais como dos párias na Índia, dos leprosos na Antiguidade e dos aidéticos nos dias de hoje. No mesmo ano, em contraposição à ideia de novidade, tão ressaltada em alguns textos da coletânea de Paugan (1996), argumenta-se que a novidade não estava nem no termo nem no conceito de exclusão, "mas no fato - este, sim, recente - de o mesmo haver-se tornado categoria-chave em praticamente todas as ciências humanas, na frequência com que passou a ser usado e na densidade e, ao mesmo tempo, ambiguidade do seu conteúdo" (Ferraro, 1999a, p. 300). Decorridos alguns anos, Oliveira (1994, p. 25), contrapondo-se a autores para quem o termo exclusão teria aparecido na França nas últimas décadas, sustenta que o termo exclusão, assim como uma série de expressões equivalentes, já podia ser encontrado, "de modo bastante pertinente", na obra de Marx.

4 O sobrenome do primeiro autor deste artigo era Ferrari até ano de 1992, quando foi retificado para Ferraro. 
Em segundo lugar, há que se registrar que os questionamentos foram dirigidos principalmente a Touraine (1991), que via na exclusão um novo paradigma que teria vindo em substituição ao paradigma de classes. Para Ribeiro (1999), os limites inerentes ao termo exclusão podiam ser remetidos à sua proximidade com o pensamento de Durkheim, o que aparecia em conceitos como marginalização (Castel, 1997; Touraine, 1991), desfiliação (Castel, 1997) e dessocialização (Thomas, 1997). Segundo a autora,

Como em um passe de mágica, Touraine (1991) coloca as diferenças, que antes separavam as classes entre "os de cima e os de baixo", superadas por uma sociedade horizontal que separa os que estão dentro (in) dos que estão fora (out), sem explicar o movimento que provoca tal milagre. Sua preocupação é a de que, na sociedade francesa, a segregação dê origem ao ghetto existente na sociedade americana. (Ribeiro, 1999, p. 35)

Ferraro (1999b), por sua vez, dizia que o recurso ao termo exclusão em estudos sobre alfabetização e escolarização não significava de forma alguma que se estivesse tomando a noção de exclusão como um novo paradigma, como pretendia Touraine. E argumentava que a visão de sociedade desse autor focalizava diferentes estágios, não o processo em si de desenvolvimento social, e que, nessa perspectiva, "a sociedade da exclusão teria substituído a sociedade de classes, assim como, para Durkheim, a sociedade fundada na solidariedade orgânica teria ocupado o lugar deixado pela sociedade fundada na solidariedade mecânica" (Ferraro, 1999b, p. 24).

Alguns anos depois, buscando definir o alcance e os limites do conceito de exclusão, Oliveira (2004, p. 23, 110, 151 e 153, grifos do original) aprofunda esse ponto dizendo que "O eminente autor francês [Touraine] nem sequer levanta a suspeita de que a integração social tão almejada possa ser uma forma de inclusão subordinada"; que "a perspectiva crítica é alcançada revelando-se que a lógica do capital inclui a exclusão"; que "o conceito de exclusão não é capaz de consubstanciar um novo paradigma social'; e, finalmente, que a vocação mais clara da ideia de exclusão é "funcionar como conceito descritivo".

Assim, enquanto dotado de poder meramente descritivo, o conceito de exclusão está longe de poder igualar e substituir o conceito de classes sociais no que diz respeito a potencial explicativo.

Mais recentemente, Frigotto (2010, p. 419-420) alertou para o risco do uso abusivo dessa noção de exclusão, risco este que estaria na possibilidade de nos fixarmos no sintoma e nas consequências das formas que assumem as relações sociais capitalistas nos dias atuais, o que nos poderia levar a uma postura reformista e conservadora, quando, no contexto do capitalismo de hoje, a solução para o problema da exclusão social estaria não na inclusão social, mas na questão mais radical da emancipação humana.

A partir do final dos anos de 1990, multiplicaram-se também os estudos sobre exclusão escolar. Assim, referindo-se à expansão da educação infantil ocorrida no Governo Geisel e em desdobramentos posteriores, Rosemberg $(1999$, p. 7) 
identifica o que ela chamou de "novos processos de exclusão criados pela política de 'democratização' da educação infantil”. Nesse mesmo ano é publicado artigo em que se desenvolve diagnóstico da escolarização no Brasil na perspectiva da exclusão escolar (Ferraro, 1999b), artigo este que serviu de inspiração teórica e metodológica para o presente estudo.

No ano seguinte, em artigo sobre o tema da relação entre exclusão social e fracasso escolar, Spozati (2000, p. 30-31) afirma a atualidade do tema, mas reconhecendo que a exclusão como processo remonta aos primórdios da história humana; afirma ainda que seria um erro tomar a exclusão social como sinônimo de miséria e pobreza, denunciando a "relação de cumplicidade da escola com a exclusão social" e enfatizando a necessidade de "dar um salto de qualidade e comprometer a escola, a sala de aula e as atividades educativas com o processo mais amplo de inclusão social". Kuenzer (2005), por sua vez, tratando da nova forma de dualidade estrutural objetivada nas relações entre educação e trabalho, fala em exclusão includente e inclusão excludente.

Decorridos alguns anos, Drago e Rodrigues (2008) sustentam que qualquer proposta de educação inclusiva tem que ser mais que a simples matrícula do indivíduo na escola comum. Para os autores, há que dar outra lógica à escola, transformando suas práticas, suas relações interpessoais, sua formação, seus conceitos.

No que respeita à exclusão escolar, é manifesto, em alguns textos aqui citados, o entendimento de que, para se resolver o problema da exclusão escolar, não basta colocar todo mundo dentro da escola; há que se transformar a própria escola - a lógica de exclusão que rege o seu funcionamento. É o que se desenvolverá no ponto seguinte.

\section{INCLUIR RESOLVE?}

Se há exclusão, e se a exclusão repugna, coloca-se a questão de como solucionar esse problema. Numa perspectiva não dialética, com foco em estados ou situações de exclusão, não em processos, a inclusão surge naturalmente como solução, de sorte que a onda da exclusão se faz logo acompanhar pelo que se poderia chamar de onda da inclusão. Tem gente fora [out]? Há que por para dentro [in]! Essa visão, largamente dominante, foi denunciada por pesquisadores que tentaram analisar a questão em uma perspectiva dialética.

Contrapondo-se à corrente dominante, e a Touraine em particular, Ribeiro $(1999$, p. 36) sustenta que o fato de se viver um momento de luta de classes em que a correlação de forças era (e é) favorável ao capital não significa que as camadas populares tenham perdido a capacidade de lutar e de tomar iniciativas. Para a autora, "a exclusão está incluída na própria dinâmica do processo de produção capitalista": na forma imprecisa como é utilizado, o termo exclusão "desloca a atenção da luta de classes, que se dá no coração da produção capitalista, para a luta por políticas sociais compensatórias (de inserção e/ou de inclusão)" (Ribeiro, 1999, p. 37, grifo do original).

Com efeito, de que valeria incluir em uma escola ou sociedade que continuasse a reger-se pela lógica da exclusão? Em termos dialéticos, o caminho 
deveria ser buscado na "negação da negação", na "exclusão da exclusão", como diz Oliveira (2004, p. 76). A propósito, pode-se também lembrar o que já fora dito antes a respeito da escola brasileira, a saber, que, "se o que temos é exclusão socialmente produzida, a solução é deixar de excluir" e que, assim, "o primeiro passo é a vontade política de não mais excluir, [...] de universalizar o acesso à escola e de estender a todos as condições de permanência e progressão na escola" (Ferrari, 1987, p. 96).

A ideia da universalização como caminho aparece com força em $A$ educação para além do capital, em que Mészáros (2010, p. 65, grifos do original) afirma que, para a efetiva transcendência da autoalienação do trabalho, há que se colocar em primeiro plano dois conceitos fundamentais: "A universalização da educação e a universalização do trabalho como atividade humana autorrealizadora". A esse respeito, entende-se que seria no mínimo um equívoco pensar a universalização da educação básica como resultado simplesmente de políticas de inclusão escolar, se essa inclusão se dá em uma sociedade e em uma escola regidas por uma lógica de “exclusão e inclusão subordinada"(Oliveira, 2004). Coisa esta, aliás, tão bem descrita por Marx nos Grundrisse, na parte em que se refere à expropriação dos camponeses, transformados, primeiro, em uma massa imensa a que se aplicou o rótulo, ou melhor, o estigma de vagabundos e que, depois, em um processo lento, plurissecular, foram sendo novamente incorporados, mas agora na forma de trabalho assalariado (subordinado). Afirma Marx:

[...] o trabalho assalariado não é criado em sua plenitude senão pela ação do capital sobre a propriedade da terra, e, portanto, uma vez que esta se tenha consolidado como forma, pelo proprietário mesmo da terra. Este, como diz Stuart, limpa [clears], então, a terra de suas bocas supérfluas, arranca os filhos da terra do peito que os criou e transforma deste modo a agricultura, que, segundo a sua natureza, se apresenta como fonte direta de subsistência, em fonte mediata de subsistência, completamente dependente de relações sociais [das relações de trabalho assalariado]. (Marx, 1987, v. 1, p. 218, grifo do original)

\section{COMO AVALIAR A EXCLUSÃO ESCOLAR}

Em que pesem as limitações apontadas, a ideia dos autores aqui não é abandonar o uso do termo exclusão em diagnósticos da escolarização, mas recorrer a ele no sentido estrito, como foi utilizado nos trabalhos já citados; jamais como um novo paradigma em substituição ao paradigma de classes sociais. Obviamente, o recurso ao termo exclusão em diagnósticos da escolarização requer que se esclareçam previamente quais os parâmetros a serem utilizados no estudo.

Foi a Constituição de 1934 que, pela primeira vez, no Brasil, afirmou explicitamente a educação como direito de todos e estabeleceu em nível constitucional os princípios da obrigatoriedade do ensino primário e de sua gratuidade nas escolas públicas (Poletti, 2001, artigos 149 e 150, § único, letra a). Mas a referida Constituição não previa ainda instrumentos legais para os sujeitos (cidadãos) poderem 
cobrar do Estado esse direito, coisa para a qual um conceituado constitucionalista chamara atenção no ano anterior à Constituição de 1934: "Uma coisa é dizer-se que haverá escolas públicas e outra que todos terão escola pública. Há direitos declarados só verbalmente e de difícil reconhecimento, e direitos subjectivos, accionáveis"(Pontes de Miranda, 1933, p. 7, grifos do original).

Foi necessário aguardar pela redemocratização e o movimento constituinte para que se pudesse ver reconhecida a educação (fundamental, no caso) como direito público subjetivo acionável (Tácito, 2004, artigo 208, inciso I, § $1^{\circ}$ e $2^{\circ}$ ). Posteriormente, o artigo 3º da Lei de Diretrizes e Bases de 1996 foi alterado, estendendo o ensino fundamental obrigatório de 8 para 9 anos, com início aos 6 anos de idade (Brasil, lei n. 11.274/2006). Finalmente, a emenda constitucional n. 59 (Brasil, 2009) estendeu a obrigatoriedade a toda a educação básica, dos 4 aos 17 anos, elevando todos os três níveis - a educação pré-escolar, o ensino fundamental e o ensino médio - à condição de direito público subjetivo, mudança esta com prazo até 2016 para implementação.

Essas mudanças na legislação, operadas no quinquênio anterior ao Censo 2010, complicam, em alguma medida, tanto a organização dos dados censitários quanto a sua interpretação. As Tabelas 1 e 2 representam o primeiro passo nessa tarefa. Elas apresentam o resultado, respectivamente em números absolutos e percentuais, do cruzamento da população de 4 a 17 anos com curso/grau e ano/série frequentados. $\mathrm{Na}$ realidade, optou-se por incluir também a população de 18 anos, para se poder avaliar a situação imediatamente após a faixa de escolarização obrigatória. Em relação ao ensino fundamental, o Instituto Brasileiro de Geografia e Estatística (IBGE) manteve a classificação de oito séries ( $1^{\mathrm{a}}$ série, $2^{\mathrm{a}}$ série...) para a população escolar regida pela legislação anterior, com obrigatoriedade dos 7 aos 14 anos, criando nova classificação de nove anos ( $1^{\circ}$ ano, $2^{\circ}$ ano... $9^{\circ}$ ano) para a população escolar regida pela lei n. 11.274/2006, com obrigatoriedade dos 6 aos 14 anos.

Foram dois os princípios ou critérios básicos que regeram a organização tabular. O primeiro foi o de distinguir, para cada idade, a presença ou não no sistema escolar no momento do Censo, para se poder avaliar quantitativamente a exclusão $d a$ escola. O segundo foi a relação esperada entre idade e grau/série ou ano: 6 anos $1^{\circ}$ ano; 7 anos $-1^{\mathrm{a}}$ série ou $2^{\circ}$ ano e assim por diante, no intuito de se obter as taxas de exclusão $n a$ escola, entendida esta como frequência fortemente defasada, isto é, com dois ou mais anos de defasagem em relação ao que seria a frequência no/a ano/série esperado/a.

Dito isso, pode-se passar à análise, iniciando-se pela exclusão da escola.

\section{EXCLUSÃO DA ESCOLA}

De acordo com a legislação então em vigor, no momento do Censo 2010 deveriam estar frequentando escola pelo menos todas as crianças e adolescentes de 6 a 14 anos. Nesse grupo de idade, o total de não frequência (de exclusão da escola) somava quase um milhão de crianças e adolescentes (966.305), com percentuais máximos aos 6 anos $(5 \%)$ e aos 14 anos $(5,8 \%)$ e percentual mínimo $(2,1 \%)$ aos 9 anos (Tabelas 1 e 2). 

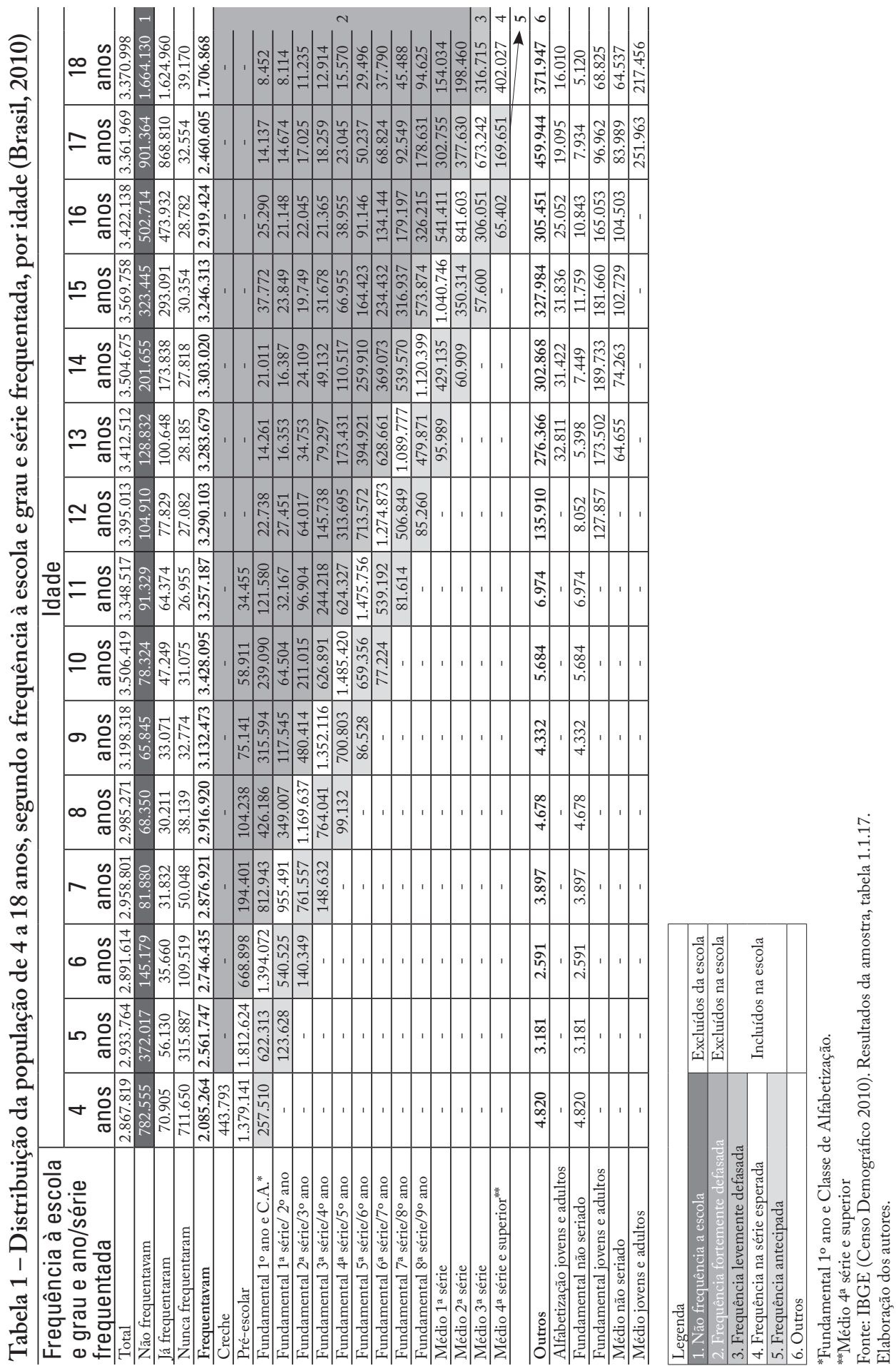

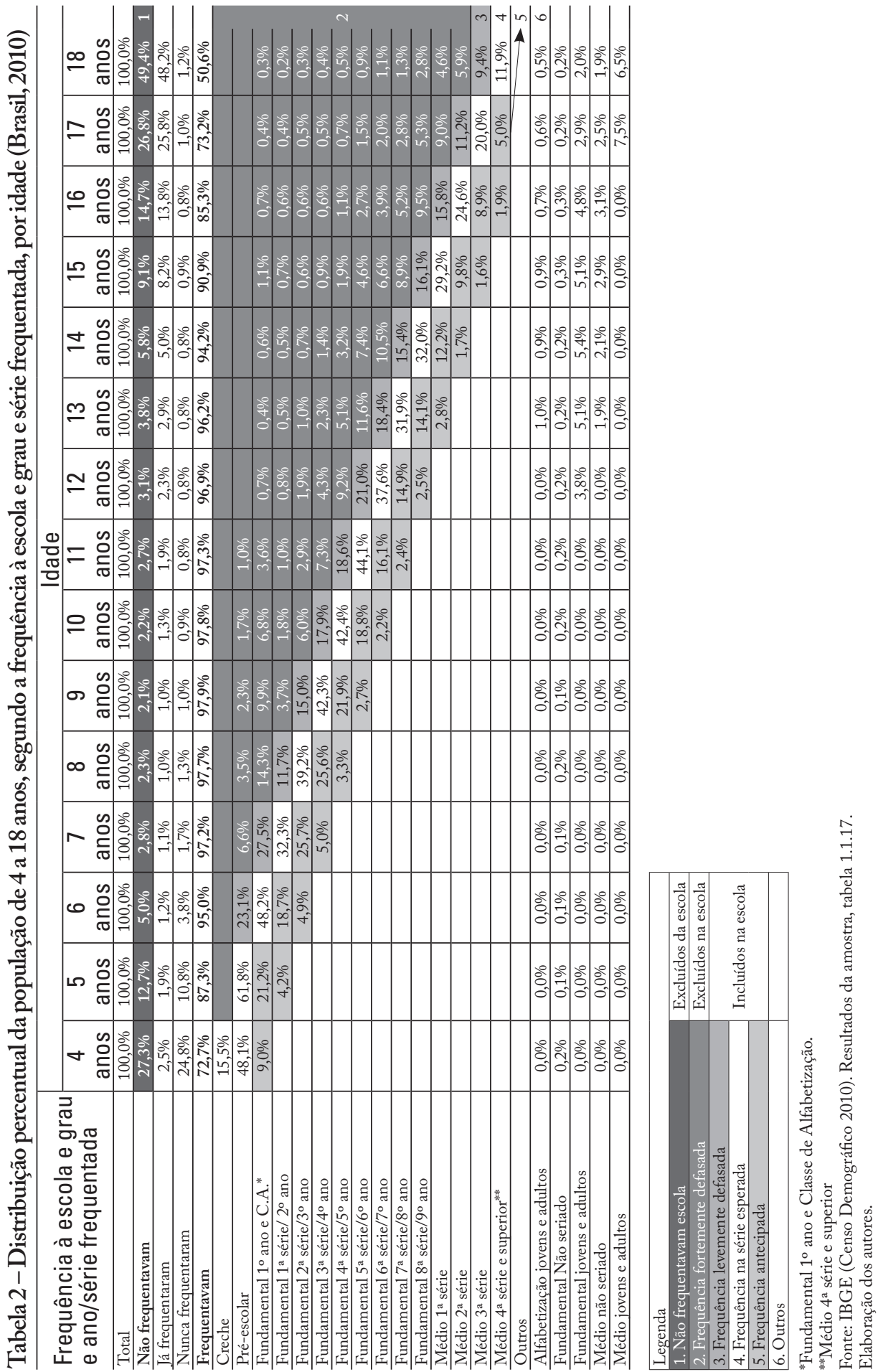
Têm-se aí números absolutos e percentuais relativamente baixos de exclusão da escola em 2010, se comparados com os montantes e taxas de não frequência apurados nos trinta anos anteriores. A Tabela 3 apresenta os índices de redução da exclusão da escola ao longo do período de 1980 a 2010. Considerando os cinco levantamentos do IBGE que ali constam, o Brasil chegou a 2010 com uma taxa de exclusão da escola para a população de 7 a 14 anos equivalente a 11,3\% do montante de 1980. Em termos absolutos, isso significa uma redução no número de excluídos da escola, sempre na faixa de 7 a 14 anos, de quase 7,6 milhões em 1980 para, sucessivamente, cerca de 5,7 milhões em 1991, 2,7 milhões em 1996 e 1,5 milhões em 2000, até pouco mais de 850 mil em 2010.

A análise da trajetória das taxas de exclusão da escola, de levantamento a levantamento da população nessa mesma faixa de idade, revela uma redução mais acentuada no quinquênio 1991/1996. A propósito, há que se lembrar de que quase 70\% do quinquênio, que vai do Censo 1991 a Contagem da População 1996, em que a queda da exclusão da escola foi mais acentuada, referem-se aos governos Fernando Collor de Mello e Itamar Franco!

Passa-se a considerar agora toda a população que, até 2016, deverá ser incorporada ao sistema escolar, isto é, todas as crianças e adolescentes de 4 a 17 anos, procurando verificar o andamento da taxa de exclusão da escola nas sucessivas idades. Os percentuais de não frequência à escola verificados na Tabela 4 revelam valores máximos de exclusão da escola nas idades extremas: 4 anos e 17 anos. Partindo de um valor máximo da ordem de 27,3\% entre as crianças de 4 anos, a taxa de exclusão da escola cai sucessivamente até atingir o valor mínimo de 2,1\% aos 9 anos, elevando-se, a partir daí, até alcançar 26,8\% aos 17 anos — praticamente o mesmo nível verificado no ponto de partida (4 anos). A representação gráfica dos percentuais de não frequência à escola (de exclusão da escola) dos 4 aos 17 anos resulta numa curva não linear em forma de "U", com valores inferiores a $6 \%$ em todas as idades de escolarização obrigatória até o ano anterior ao Censo 2010 (6 a 14 anos) (Gráfico 1).

O grande desafio posto pela emenda constitucional n. 59/2009 está precisamente nas extremidades dos novos limites da escolarização obrigatória, que até 2016 deverá compreender toda a população de 4 até 17 anos. A consideração da não frequência

Tabela 3 - Índices de redução da exclusão da escola de censo a censo ou contagem da população (Brasil, 1980 a 2010)

\begin{tabular}{l|c|c|c|c|c|c}
\hline Ano & $\begin{array}{c}\text { Total de não } \\
\text { frequentes }\end{array}$ & \multicolumn{1}{|c|}{$\begin{array}{c}\text { Percentual } \\
\text { (base1980) }\end{array}$} & \multicolumn{4}{|c}{$\begin{array}{c}\text { Percentual } \\
\text { (base móvel) }\end{array}$} \\
\hline 1980 & 7.553 .741 & $100,0 \%$ & $100,0 \%$ & & & \\
\hline 1991 & 5.663 .596 & $75,0 \%$ & $75,0 \%$ & $100,0 \%$ & & \\
\hline 1996 & 2.650 .203 & $35,1 \%$ & & $46,8 \%$ & $100,0 \%$ & \\
\hline 2000 & 1.495 .639 & $19,8 \%$ & & & $56,4 \%$ & $100,0 \%$ \\
\hline 2010 & 851.126 & $11,3 \%$ & & & & $56,9 \%$ \\
\hline
\end{tabular}

Fontes: IBGE (Censos Demográficos 1980, 1991, 2000 e 2010) e Contagem da População 1996.

Elaboração dos autores. 


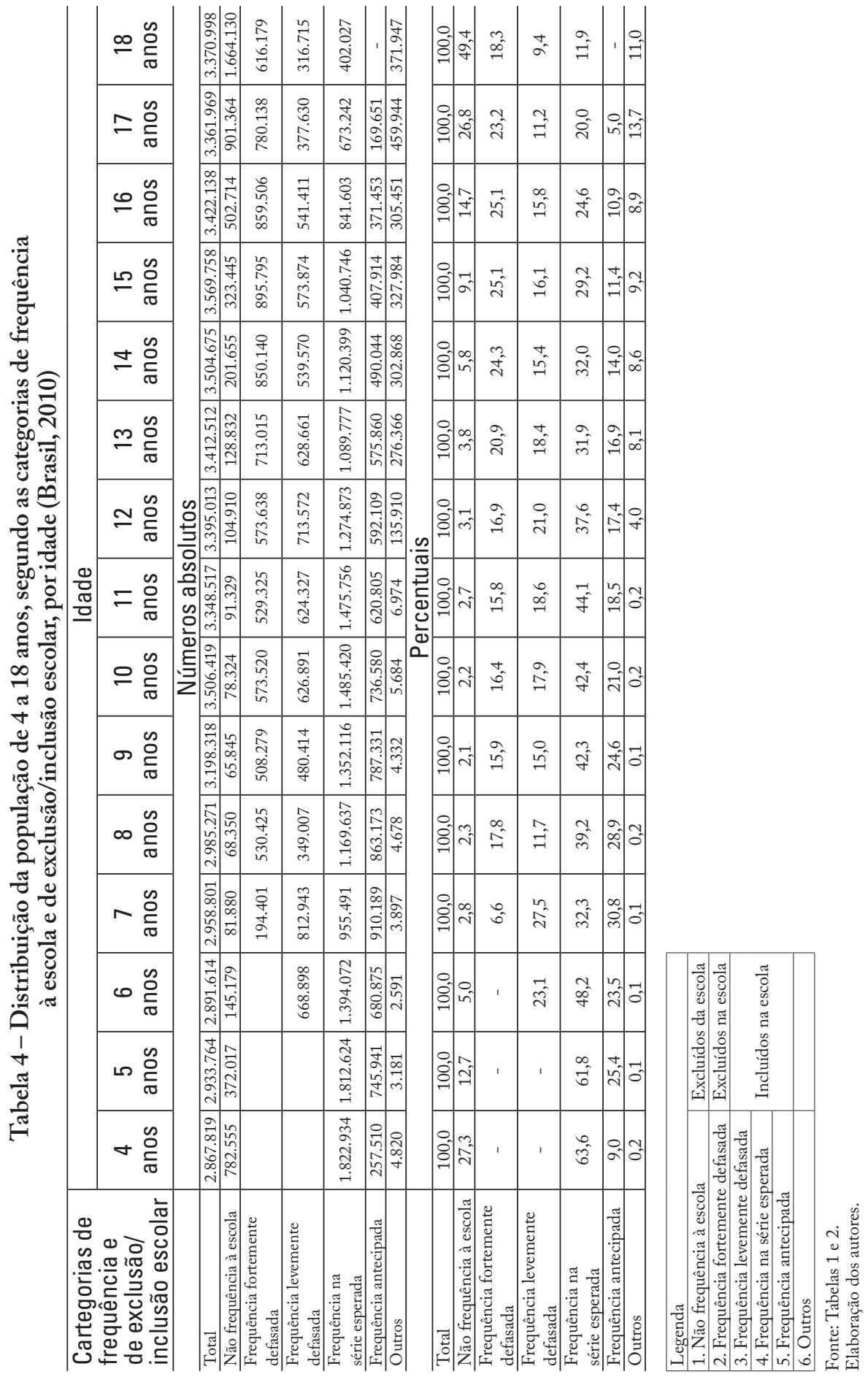


nos grupos de 4 a 5 e 15 a 17 anos nos permite, assim, avaliar o tamanho da tarefa a ser cumprida até o prazo de implementação da emenda constitucional n. 59/2009. Com efeito, no grupo de 15 a 17 anos, a não frequência à escola, que somava 4,3 milhões em 1980, 4,1 milhões em 1991, 3,4 milhões em 1996 e 2,4 em 2000, representava ainda, em 2010, um saldo negativo considerável, superior a 1,7 milhões de adolescentes nesse grupo de idade a serem incorporados ao sistema escolar até 2016 (Tabela 5).

Como se pode conferir na Tabela 5 , as taxas máximas de não frequência à escola em 2010 nas idades de 4 anos $(27,3 \%)$ e 17 anos $(26,8 \%)$ situam-se no mesmo patamar das taxas mínimas de não frequência (entre $25,9 \%$ e $28,7 \%$ ) apuradas em 1980 entre as crianças de 9 a 12 anos, taxas, estas últimas, que levaram trinta anos para baixar ao nível de $2 \%$ a $3 \%$. A seguir, nesse mesmo ritmo, teríamos que aguardar até 2040 para ver a redução das taxas de não frequência para o nível de $2 \%$ a $3 \%$ entre as crianças de 4 anos e os adolescentes de 17 anos. No entanto, a queda mais acentuada, de 2000 a 2010, no número absoluto de excluídos da escola entre as crianças de 4 anos do que entre os adolescentes de 17 anos (Tabela 5), sugere dificuldade maior na incorporação destes últimos ao sistema escolar. A Pesquisa Nacional por Amostra de Domicílios (PNAD), de 2013 (IBGE, 2013), confirma essa previsão, ao revelar que o número absoluto de adolescentes de 15 a 17 anos que não frequentavam escola não diminuiu no triênio 2010-2013.

Os dois grupos de idade que tiveram a obrigatoriedade estabelecida pela emenda constitucional n. 59/2009 somavam nada menos que 2.244 .717 crianças e

\section{Gráfico 1 - Distribuição percentual das pessoas de 4 a 18 anos, segundo as categorias de exclusão e inclusão escolar, por idade. Brasil, 2010}

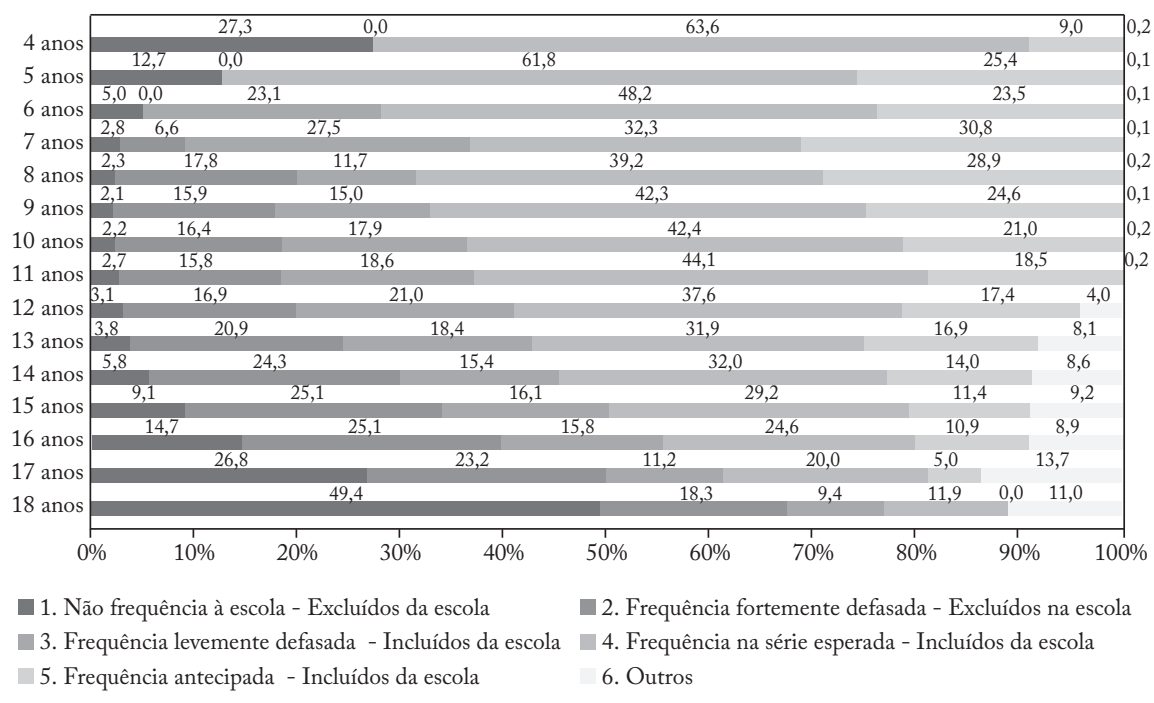




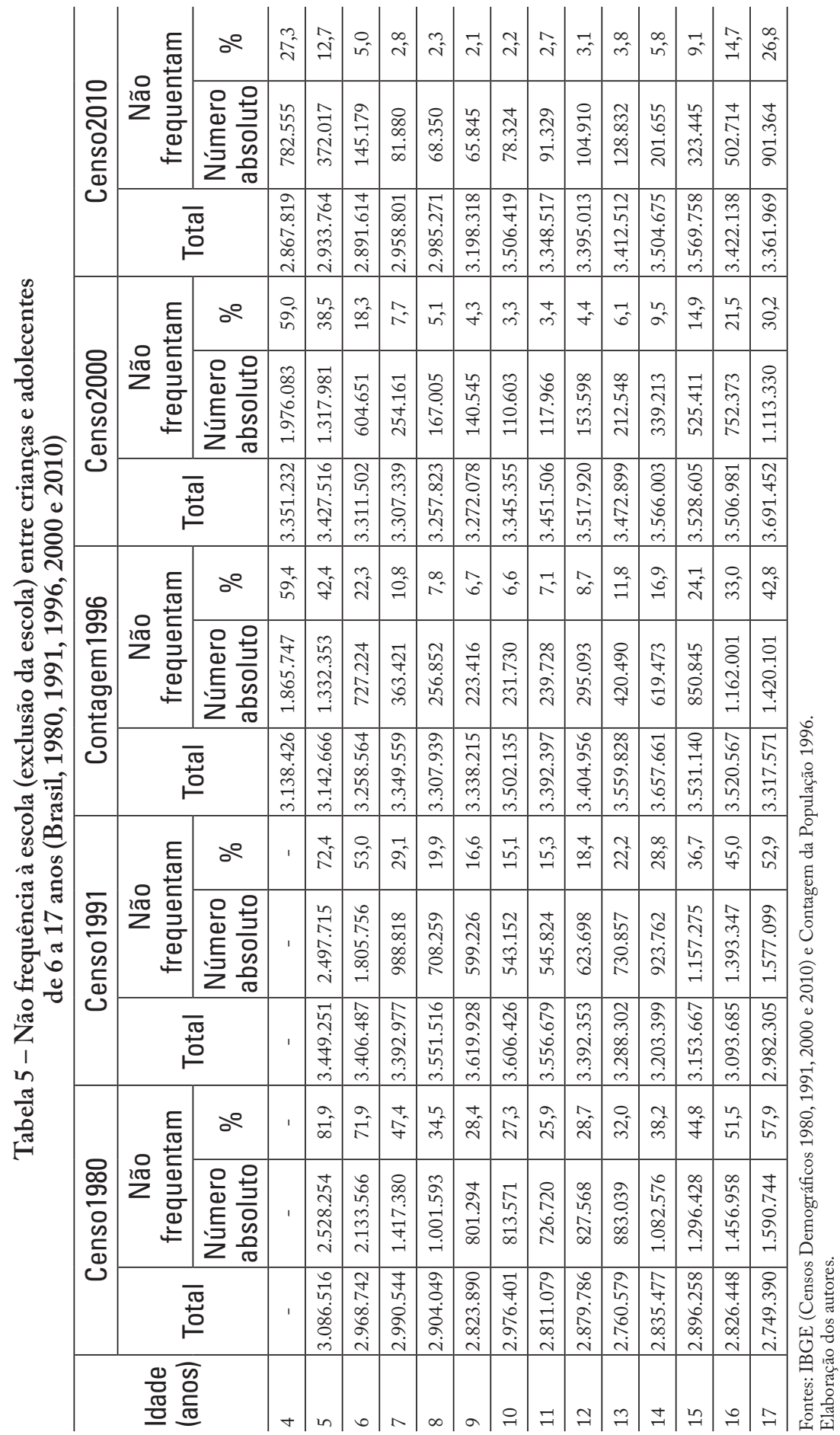


adolescentes que não frequentavam escola (de excluídos da escola) no momento do Censo 2010, sendo 517.196 no grupo de 4 a 5 anos e 1.727 .523 no grupo de 15 a 17 anos: o primeiro grupo, referido à pré-escola; o segundo, ao ensino médio. Adicionando-se a esses valores a não frequência no grupo de 6 a 14 anos (966.304), o total de crianças e adolescentes de 4 a 17 anos fora da escola no momento do Censo de 2010 alcança a vultosa cifra de 3.211.021. Esse é o tamanho do desafio a ser vencido até 2016 no que diz respeito à incorporação obrigatória ao sistema escolar, isto é, de universalização da escolarização de crianças e adolescentes dos 4 aos 17 anos.

A avaliação que se acaba de fazer pautou-se pelo número absoluto da não frequência à escola, por se entender que essa maneira de avaliar é melhor que a consideração de números percentuais para dimensionar o desafio a ser enfrentado pelo poder público. Em termos relativos, a já citada PNAD (IBGE, 2013) acusou as seguintes taxas de escolarização: 4 a 5 anos — 78,1\%; 6 a 14 anos - 98,2\%; 15 a 17 anos - 84,2\%. Isso confirma que o desafio de universalização da escolarização dos 4 aos 17 anos está posto principalmente nas pontas, ou melhor, nas idades tidas como próprias das etapa inicial e final da educação básica — a pré-escola e o ensino médio. Os valores mais elevados de não frequência em 2010 aparecem nas idades extremas da escolarização obrigatória em implantação pela emenda constitucional n. 59/2009: 27,3\% entre as crianças de 4 anos, e 26,8\% entre os adolescentes de 17 anos. Em ambos os casos, valores superiores a um quarto do respectivo total.

Em síntese, mesmo se reconhecendo o significativo avanço do país no que se refere ao acesso à escola no período de 1980 a 2010, não há como ignorar o desafio posto pelo preceito constitucional de universalização da frequência à escola de toda a população de 4 a 17 anos. Obviamente, se a questão for pensada em universalização da educação básica, o problema é bem mais complexo: a universalização da frequência à escola dos 4 aos 17 anos não garante, por si só, a universalização da educação básica (pré-escola, ensino fundamental e ensino médio). Com isso se pode passar à exclusão na escola.

\section{EXCLUSÃO NA ESCOLA}

A Tabela 4 agrupa, em números absolutos e percentuais, os dados das Tabelas 1 e 2 . Tal agrupamento destaca em primeiro lugar a categoria dos excluídos da escola, coisa que se acabou de examinar.

A segunda categoria é a dos excluídos na escola, compreendendo todas aquelas crianças e adolescentes que, em 2010, apresentavam uma defasagem na relação idade-série igual ou superior a dois anos, chamada também de frequência fortemente defasada (Tabelas 1 e 2). Em números absolutos (Tabela 4), o total de crianças e adolescentes (de 7 a 17 anos, no caso) com dois ou mais anos de defasagem nos estudos (excluídos na escola) continuava elevado em todas as idades, somando nada menos que sete milhões em 2010.

Como se pode também conferir na Tabela 4 , a taxa de alunos e alunas com dois anos ou mais de defasagem nos estudos, que inicia com 6,6\% entre as crianças de 7 anos, significando crianças que, nessa idade, ainda estavam na pré-escola, salta logo para taxas situadas entre $15,8 \%$ e $17,8 \%$ nas idades de 8 a 12 anos e para $20,9 \%$ a $25,1 \%$ nas idades de 13 a 17 anos, com tendência a cair a partir dos 17 anos, em decorrência, 
certamente, da elevação das taxas de não frequência, especialmente a partir dessa idade. Esses números permitem dizer que, segundo o Censo 2010, a exclusão na escola (a frequência fortemente defasada na relação entre grau/ano ou série e idade) atinge aproximadamente um em cada seis estudantes de 8 a 12 anos (um sexto) e um em cada quatro a cinco estudantes a partir dos 13 até 17 anos (entre um quarto e um quinto).

Já se mostrou, anteriormente, que, de 1980 a 2010, obteve-se uma redução acentuada no contingente de excluídos da escola. De maneira semelhante, embora em proporção menor, houve também, da Contagem da População 1996 (Tabela 4 e Gráfico 1) (Ferraro, 1999b) ao Censo 2010, redução da exclusão na escola (do contingente e percentual de alunos/as fortemente defasados/as nos estudos).

No entanto, esses ganhos não devem levar a menosprezar os desafios ainda postos na universalização da escolarização básica. Como se pode ver na Tabela 6, a taxa do conjunto de exclusão da escola e exclusão na escola, que já é de 9,3\% aos 7 anos (crianças ainda na pré-escola), sobe para valores entre $18 \%$ a $20,1 \%$ dos 8 aos 12 anos, elevando-se sucessivamente para $24,7 \%$ aos 13 anos, $30 \%$ aos 14 anos, $34,2 \%$ aos 15 anos, $39,8 \%$ aos 16 anos e $50 \%$ aos 17 anos.

A exclusão na escola pode ser apreciada também com base nas trajetórias das taxas referentes às três subcategorias reunidas na categoria inclusão na escola, a saber: os antecipados na relação ano ou série/idade, aqueles que se encontram na série esperada para cada idade e os levemente defasados (um ano de atraso).

Tabela 6 - Número absoluto e percentual de crianças e adolecentes de 7 a 17 anos, com frequência à escola fortemente defasada e não frequência, por idade (Brasil, 2010)

\begin{tabular}{l|c|c|c|c|c|c|c}
\hline \multirow{2}{*}{$\begin{array}{l}\text { Idade } \\
\text { (anos) }\end{array}$} & \multirow{2}{*}{$\begin{array}{c}\text { Total } \\
\text { geral }\end{array}$} & \multicolumn{2}{c|}{$\begin{array}{c}\text { Não } \\
\text { frequência }\end{array}$} & \multicolumn{2}{c|}{$\begin{array}{c}\text { Frequência } \\
\text { fortemente } \\
\text { defasada }\end{array}$} & \multicolumn{2}{c}{$\begin{array}{c}\text { Não frequência } \\
\text { frequência } \\
\text { fortemente defasada }\end{array}$} \\
\cline { 3 - 9 } & & $\begin{array}{c}\text { Número } \\
\text { absoluto }\end{array}$ & $\%$ & $\begin{array}{c}\text { Número } \\
\text { absoluto }\end{array}$ & $\%$ & $\begin{array}{c}\text { Número } \\
\text { absoluto }\end{array}$ & $\%$ \\
\hline 7 & 2.958 .801 & 81.880 & 2,8 & 194.401 & 6,6 & 276.281 & 9,3 \\
\hline 8 & 2.985 .271 & 68.350 & 2,3 & 530.425 & 17,8 & 598.775 & 20,1 \\
\hline 9 & 3.198 .318 & 65.845 & 2,1 & 508.279 & 15,9 & 574.124 & 18,0 \\
\hline 10 & 3.506 .419 & 78.324 & 2,2 & 573.520 & 16,4 & 651.844 & 18,6 \\
\hline 11 & 3.348 .517 & 91.329 & 2,7 & 529.325 & 15,8 & 620.654 & 18,5 \\
\hline 12 & 3.395 .013 & 104.910 & 3,1 & 573.638 & 16,9 & 678.549 & 20,0 \\
\hline 13 & 3.412 .512 & 128.832 & 3,8 & 713.015 & 20,9 & 841.847 & 24,7 \\
\hline 14 & 3.504 .675 & 201.655 & 5,8 & 850.140 & 24,3 & 1.051 .795 & 30,0 \\
\hline 15 & 3.569 .758 & 323.445 & 9,1 & 895.795 & 25,1 & 1.219 .240 & 34,2 \\
\hline 16 & 3.422 .138 & 502.714 & 14,7 & 859.506 & 25,1 & 1.362 .220 & 39,8 \\
\hline 17 & 3.361 .969 & 901.364 & 26,8 & 780.138 & 23,2 & 1.681 .501 & 50,0 \\
\hline
\end{tabular}

Fonte: IBGE (Censo Demográfico 2010).

Elaboração dos autores. 
Em primeiro lugar, a frequência antecipada na relação ano ou série/idade, que já atinge a taxa de $9 \%$ das crianças de 4 anos já frequentando o $1^{\circ}$ ano do fundamental ou classes de alfabetização, salta para $25,4 \%$ aos 5 anos e $30,8 \%$ aos 7 anos, caindo, a partir daí, ano a ano, até a inexpressiva taxa 5\% de adolescentes antecipados aos 17 anos, isto é, já cursando o ensino médio (Tabela 2). É como se o sistema escolar se encarregasse de segurar os apressadinhos e as apressadinhas!

Quanto à frequência na série esperada, as taxas máximas, superiores a 60\%, aos 4 e 5 anos, vão logo caindo, de forma um tanto irregular, para taxas entre $50 \%$ e $30 \%$, e, finalmente, no grupo de idade correspondente ao ensino médio (15 a 17 anos), para taxas entre $30 \%$ e $20 \%$. Mesmo que, em sua maioria, ingressem na série esperada, grande parte dos/as alunos/as sofre atraso nos estudos em consequência principalmente de reprovações (Tabela 2).

É bem mais irregular o movimento da taxa dos levemente defasados, mas situada sempre entre $11,2 \%$ e $27,5 \%$ (Tabela 2), representando essa categoria uma situação intermediária entre os joãozinhos e mariazinhas do passo certo e a categoria numericamente expressiva dos fortemente defasados, também chamados de excluídos na escola.

A categoria Outros compreende a alfabetização de jovens e adultos, fundamental não seriado, fundamental de jovens e adultos, médio não seriado e médio de jovens e adultos. Não passando de $0,2 \%$ até os 11 anos, a taxa de frequência na categoria Outros já sobre para $4 \%$ aos 12 anos e para $8,1 \%$ a 9,2\% aos 13 a 16 anos, alcançando 13,7\% aos 17 anos. Surpreende que, mesmo na faixa de escolarização obrigatória anterior à emenda constitucional n. 59/2009, cerca de $8 \%$ dos adolescentes de 13 e 14 anos já estivessem fora do ensino fundamental regular, isto é, frequentado cursos alternativos, em princípio destinados a jovens e adultos que ultrapassaram a idade de escolarização obrigatória (Tabela 4).

\section{APÓS OS 17 ANOS}

Nas tabelas e gráficos apresentados foi incluída a população de 18 anos com o propósito bem específico de apurar qual a situação, em relação à frequência à escola, na idade imediatamente seguinte à faixa de escolarização obrigatória definida pela emenda constitucional n. 59/2009. Como se pode conferir na Tabela 2 e no Gráfico 1, a taxa de não frequência quase duplica dos 17 para os 18 anos, saltando de $26,4 \%$ para $49,4 \%$. Somando-se a esses $49,4 \%$ os $18,3 \%$ fortemente defasados nos estudos, a taxa de exclusão escolar ( $d a$ escola e na escola) entre os jovens de 18 anos atinge um total de $67,7 \%$. Ou seja, no ano de 2010, a cada três jovens de 18 anos, dois estavam fora da escola ou estavam fortemente defasados nos estudos.

Outra maneira de examinar essa questão é considerar o grupo de jovens de 18 e 19 anos à luz do critério nível de instrução atingido em 2010. Note-se que esse grupo, pela idade, deveria estar com o ensino médio concluído. O Censo 2010 (IBGE, 2010), no entanto, revela que 60,8\% (quase dois a cada três jovens) não haviam ainda concluído o ensino médio nesse ano, sendo que, entre esses, 26,8\% (um a cada quatro jovens) figuravam na categoria "sem instrução e ensino fundamental incompleto", e outros 34\%, na categoria "ensino fundamental completo e médio 
incompleto". Nesse grupo de idade (18 e 19 anos), apenas 37,6\% haviam concluído o ensino médio - pouco mais de um terço.

Essas últimas constatações vêm reforçar a ideia de que a universalização da educação básica representa desafio bem maior do que aquele dimensionado pela obrigatoriedade escolar dos 4 aos 17 anos, como definido pela emenda constitucional n. 59/2009. Em outras palavras, não basta incluir na escola aqueles que ainda estão excluídos dela. Há que romper com a lógica de exclusão que continua regendo o funcionamento da escola - que continua excluindo no próprio processo de escolarização.

\section{CONCLUSÃO}

Ao concluir, há que se levar em conta, primeiramente, a discussão teórica desenvolvida e, a seguir, os resultados empíricos da investigação realizada com base principalmente no Censo Demográfico 2010.

A discussão teórica evidenciou algumas limitações inerentes à própria noção de exclusão. Em primeiro lugar, ao contrário do que alguns autores imaginam, o tema da exclusão está longe de constituir uma novidade (Ferraro, 1999b; Oliveira, 2004; Ribeiro, 1999). A novidade está no fato de o tema da exclusão se haver tornado moda - uma onda.

Em segundo lugar, o alcance da categoria exclusão é de natureza descritiva (Oliveira, 2004), não explicativa. Por isso, não basta saber se há excluídos; havendo, é necessário saber quem são eles: de que classe social, gênero, cor/raça, região, geração, religião, aspectos estes que não puderam ser abordados neste artigo.

Em terceiro lugar, justamente por seu alcance meramente descritivo, a categoria exclusão não pode ser tomada como constituindo um novo paradigma, que teria vindo em substituição ao paradigma de classes sociais, como pretende Touraine (1991). Ao contrário, a categoria exclusão só ganha relevo se articulada com categorias de potencial explicativo, como a categoria classes sociais.

Em quarto lugar, considerada a coisa na perspectiva dialética, a solução para o problema da exclusão deve ser buscada não em políticas simplistas de inclusão, mas em políticas voltadas para o rompimento da lógica de exclusão social e escolar, ou, para usar a feliz expressão de Oliveira (2004), para a exclusão da exclusão.

Em quinto lugar, dizer que o termo exclusão tem limitações não significa que ele não possa ser útil em diagnósticos da escolarização. Basta que se tenha consciência de tais limitações e que se deixe muito claro em que sentido se está utilizando a expressão exclusão. Foi o que se procurou fazer neste artigo.

Quanto aos resultados da pesquisa empírica, as análises estatísticas desenvolvidas revelaram aspectos importantes sobre a universalização do direito à educação básica. Em primeiro lugar, há que se lembrar do forte movimento de incorporação à escola, verificado a partir de 1980, do que se seguiu uma queda acentuada nas taxas de exclusão da escola.

Mas, em segundo lugar, há que se reconhecer também que o problema da exclusão da escola persiste, com mais de 850 mil crianças e adolescentes de 7 a 14 anos e quase um milhão (966.305) de 6 a 14 anos fora da escola em 2010. Se 
considerada toda a população em idade de escolarização obrigatória a partir da emenda constitucional n. 59/2009 (de 4 a 17 anos), a quantidade de excluídos da escola no momento do Censo 2010 atingia o expressivo número de mais de 3,8 milhões.

Em terceiro lugar está o fato de que o desafio de universalização do acesso está posto principalmente nas extremidades da escolarização obrigatória, correspondentes à pré-escola ( 4 e 5 anos) e ensino médio ( 15 a 17 anos), respectivamente com 1,2 e 1,7 milhões fora da escola em 2010.

Em quarto lugar está a constatação de que o problema mais grave nos ensinos fundamental e médio é aquele que reúne os alunos e alunas com mais de dois anos de defasagem nos estudos, aqui nomeados/as de excluídos/as na escola, com taxas sempre superiores a $16 \%$ a partir dos 8 anos e superiores a $20 \%$ a partir dos 13 anos, totalizando, em 2010, sete milhões de crianças e adolescentes de 7 a 17 anos nessa condição. Montante esse 32,9\% menor do que o verificado no Censo 2000, que contabilizava 10,4 milhões de alunos/as fortemente defasados/as nessa mesma faixa etária, mas representando ainda um enorme desafio pela frente.

Resta, por fim, dizer que, somadas, as duas formas de exclusão escolar atingiam, em 2010, um total de 10,8 milhões de crianças e adolescentes de 4 a 17 anos de idade: 3,8 milhões fora da escola (excluídos $d a$ escola) e sete milhões com uma defasagem de pelo menos dois anos nos estudos (excluídos na escola). A taxa de exclusão na escola é crescente a partir dos 7 anos (crianças ainda na pré-escola), atingindo o seu ponto máximo entre os adolescentes de 17 anos.

Tudo isso significa que seria uma simplificação, para não dizer uma ilusão, reduzir o objetivo da universalização do direito à educação básica a uma questão de vagas ou de acesso à escola, quando na realidade o desafio maior está dentro da escola, no próprio processo de escolarização, isto é, na necessidade de superação da lógica de exclusão que continua imperando no próprio funcionamento da escola brasileira.

Para concluir, há que se lembrar de que a Constituição Federal de 1988, em seu artigo 206, incisos I e VII, garante não só igualdade de acesso, mas também "I. Igualdade de condições para o acesso e permanência na escola" e "VII. Garantia de padrão de qualidade", o que pode ser traduzido em igualdade tanto de condições de acesso como de permanência na escola e de progressão nos estudos.

\section{REFERÊNCIAS}

Bourdieu, P.; Champagne, P. Les exclus de l'interieur. Actes de Recherche en Sciences Sociales, Paris: Persée, n. 91-92, p. 71-75, 1992. Disponível em: <http://www.persee.fr/ web/revues/home/prescript/article/arss_0335-5322_1992_num_91_1_3008>. Acesso em: 21 jun. 2014.

Brasil. Presidência da República. Constituição da República Federativa do Brasil de 1988. Diário Oficial da União, Brasília, DF, 5 out. 1988.

Brasil. Lei n. 9.394, de 20 de dezembro de 1996. Estabelece as Diretrizes e Bases da Educação Nacional. Diário Oficial da União, Brasília, DF, 23 dez. 1996a. 
BRAsil. Lei n. 11.274, de 6 de fevereiro de 2006, que altera a redação dos artigos 29, 30, 32 e 87 da Lei n. 9.394, de 20 de dezembro de 1996, que estabelece as Diretrizes e Bases da Educação Nacional, dispondo sobre a duração de 09 (nove) anos para o ensino fundamental, com matrícula obrigatória a partir dos 06 (seis) anos de idade. Diário Oficial da União, Brasília, DF, 7 fev. 2006. Seção 1,p.1. Disponível em: <http://www2.camara. leg.br/legin/fed/lei/2006/lei-11274-6-fevereiro-2006-540875-publicacaooriginal42341-pl.html>. Acesso em: 3 ago. 2013.

. Emenda constitucional n. 59, de 11 de novembro de 2009. Acrescenta § $3^{\circ}$ ao art. 76 do Ato das Disposições Constitucionais Transitórias para reduzir, anualmente, a partir do exercício de 2009, o percentual da Desvinculação das Receitas da União incidente sobre os recursos destinados à manutenção e desenvolvimento do ensino de que trata o art. 212 da Constituição Federal, dá nova redação aos incisos I e VII do art. 208, de forma a prever a obrigatoriedade do ensino de quatro a dezessete anos e ampliar a abrangência dos programas suplementares para todas as etapas da educação básica, e dá nova redação ao $§ 4^{\circ}$ do art. 211 e ao $\S 3^{\circ}$ do art. 212 e ao caput do art. 214, com a inserção neste dispositivo de inciso VI. Diário Oficial da União, Brasília, DF, 12 nov. 2009. Disponível em: <http://www.planalto. gov.br/ccivil_03/constituicao/Emendas/Emc/emc59.htm>. Acesso em: 13 jun. 2013.

CAstel, R. A dinâmica dos processos de marginalização: da vulnerabilidade à desfiliação. Caderno CRH, Salvador: UFBA, v. 10, n. 26-27, p. 19-40, 1997. Dossiê Democracia, cidadania e pobreza. A produção de novas solidariedades.

Castro, C. M. Onde está o desastre? Em Aberto, Brasília: INEP, v. 8, n. 44, p. 31-33, out./dez. 1989.

Damon, J. Vagabondage et mendicité. [France]: Flamarion, 1998.

Donzelot,J. ; Roman,J. Le déplacement de la question sociale. In: Donzelot,J.(Dir.). Face à l'exclusion. Le modèle français. Esprit, Paris: Eurozini, n. 169, p. 5-11, févr. 1991.

Drago, R.; Rodrigues, P. S. Diversidade e exclusão na escola: em busca da inclusão. Revista Facevr, Vila Velha: FACEVV, n. 1, p. 63-67, 2008.

Dubet, F. A escola e a exclusão. Cadernos de Pesquisa, São Paulo: Fundação Carlos Chagas; Campinas: Autores Associados, n. 119, p. 29-45, 2003. Disponível em: $<$ http://www.scielo.br/scielo.php?pid=S0100-15742003000200002\&script $=$ sci_ abstract\&tlng=pt $>$. Acesso em: 29 set. 2017.

Esprit. La France de l'exclusion. Paris: Eurozini, n. 182, juin 1992.

Ferrari, ${ }^{5}$ A. R. Analfabetismo no Brasil: tendência secular e avanços recentes. Resultados preliminares. Cadernos de Pesquisa, São Paulo: Fundação Carlos Chagas; Campinas: Autores Associados, n. 52, p. 35-49, fev. 1985.

. Escola e produção do analfabetismo no Brasil. Educação E Realidade, Porto Alegre: UFRGS, v. 12, n. 2, p. 81-96, jul./dez. 1987.

Ferraro, A. R. Exclusão, trabalho e poder em Marx. Sociologias, Porto Alegre: UFRGS, v. 1, n. 1, p. 300-324, jan./jun.1999a.

5 Ver nota 4. 
Ferraro, A. R. Diagnóstico da escolarização no Brasil. Revista Brasileira de Educação, Rio de Janeiro: ANPEd; Campinas: Autores Associados, n. 12, p. 22-47, set./dez.1999b. FLETCHER, P.R.A repetência no ensino de $1^{\circ}$ grau: um problema negligenciado da educação brasileira. Uma análise preliminar e sugestão de avaliação adicional. Revista Brasileira de Administração da Educação, Porto Alegre: UFRGS, v. 3, n. 1, p. 10-41, jan./jun. 1985.

Fletcher,P.R.; Castro, C.M. Os mitos, as estratégias e as prioridades para o ensino de $1^{\circ}$ grau. Educą̧ão छ Realidade, Porto Alegre: UFRGS, v. 11, n. 1, p. 35-42, jan./jun. 1986. Fletcher, P.R.; Ribeiro, S. C. O ensino de primeiro grau no Brasil de hoje. Em Aberto, Brasília: INEP, v. 6, n. 33, p. 1-10, jan./mar. 1987.

Foucault, J.-B. Exclusion, inégalités et justice sociale. Esprit, Paris: Eurozini, n. 182, p. 47-57, juin 1992.

Frigotto, G. Exclusão e/ou desigualdade social? Questões teóricas e político-práticas, Cadernos de Educação, Pelotas: UFPel, n. 37, p. 417-442, set./dez. 2010. Disponível em: $<$ http://periodicos.ufpel.edu.br/ojs2/index.php/caduc/article/view/1593>. Acesso em: 8 out. 2014.

Himmelfarb, G. La idea de la pobreza: Inglaterra a principios de la era industrial. México: Fondo de Cultura Económica, 1988.

ibGE - Instituto Brasileiro de Geografia e Estatística. Censo Demográfico 2010. Rio de Janeiro: IBGE, 2010. Disponível em: <http://www.ibge.gov.br/home/ estatistica/populacao/censo2010/educacao_e_deslocamento/default_ods.shtm $>$. Acesso em: 2014.

Pesquisa Nacional por Amostra de Domicílios 2013. Rio de Janeiro: IBGE, 2013. Disponível em: <http:/www.ibge.gov.br/home/estatistica/populacao/ trabalhoerendimento/pnad2013/default.shtm>. Acesso em: nov. 2014.

Klein, R.; Ribeiro, S. O censo educacional e o modelo de fluxo. O problema da repetência. Revista Brasileira de Estatística, Rio de Janeiro: IBGE, v. 52, n. 197-198, p. 5-45, jan./dez. 1991.

Kuenzer, A. Z. Exclusão includente e inclusão excludente: a nova forma de dualidade estrutural que objetiva as novas relações entre educação e trabalho. In: SAVIANI, D.; Safelice, J. L.; Lombardi, J. C. (Orgs.). Capitalismo, trabalho e educação. 3. ed. Campinas: Autores Associados, 2005. p. 77-96.

Lenoir, R. Les exclus, un Français sur dix. Paris: Le Seil, 1974.

Marx, K. Elementos fundamentales para la crítica de la economia politica (Grundrisse) 1857-1858. v. 1-15. Ed.; v. 2 - 11. ed.; v. 3 - 9 ed. México: Siglo Veintiuno, 1987.

MAYER, H. Les marginaux: femmes, juifs et homosexuels dans la littérature européenne. Traduit de l'allemand para Laurent Muhleisen, Maurice Jacob e Pierre Fanchini. Paris: Albin Michel, 1994.

Merrien, F.-X. État-providence et lutte contre l'exclusion. In: Paugan, S. (Dir.). L'exclusion: l'état des saviors. Paris: La Découverte, 1996. p. 417-427.

Messner, J. La cuestion social. Madrid: Rialp, 1960.

Mészáros, I. A educação para além do capital. 2. ed. São Paulo: Boitempo, 2010. 
Mollat, M. Les pauvres ao Moyen Age. Paris: Hachette, 1978.

Oliveira, A. R. Marx e a exclusão. Pelotas: Seiva, 2004.

Oliveira, L. Os excluídos "existem"? Notas sobre a elaboração de um novo conceito. São Paulo: ANPOCS, 1994. Disponível em: <http://www.anpocs.org.br/portal/publicacoes/ rbcs_00_33/rbcs33_04.htm>.Acesso em: 10 out. 2014.

Paugan, S. (Dir.). L'exclusion: l'état des saviors. Paris: La Découverte, 1996.

Perret, B. Les limites de l'insertion par le travail. Esprit, Paris: Eurozini, n. 182, p. 2334, juin, 1992.

Polettr, R. Constituiçôes brasileiras: 1934. 2. ed. Brasília, DF: Senado Federal e Ministério da Ciência e Tecnologia, Centro de Estudos Estratégicos, 2001. (Coleção Constituições Brasileiras, v. 3).

Pontes de Miranda. Direito à educação. Rio de Janeiro: Alba Limitada, 1933. (Coleção dos 5 Direitos de Homem - Sciencia e Trabalho).

Procacci, G. La naissance d'une rationalité moderne de la pauvreté. In: Paugan, S. (Dir.). L'exclusion: l'état des saviors. Paris: La Découverte, 1996. p. 405-416.

Queiroz, J.-M. Exclusion, identité e désaffection. In: Paugan, S. (Dir.). L'exclusion: l'état des saviors. Paris: La Découverte, 1996. p. 295-210.

Ribeiro, M. Exclusão: problematização do conceito. Educação e Pesquisa, São Paulo: USP, v. 25, n. 1, p. 35-49, jan./jun. 1999.

Ribeiro, S. C. A pedagogia da repetência. Estudos Avançados; São Paulo: USP, v. 5, n. 12, p. 6-21, 1991.

Ribeiro, S.C. A pedagogia da repetência. Estudos Avançados, São Paulo: USP, v. 5, n. 12, p. 6-21, 1991.

Rosemberg, F. Expansão da educação infantil e processos de exclusão. Cadernos de Pesquisa, São Paulo: Fundação Carlos Chagas; Campinas: Autores Associados, n. 107, p. 7-40, jul. 1999. Disponível em: <http://www.scielo.br/pdf/cp/n107/n107a01.pdf>. Acesso em: 8 out. 2014.

Sassier, P. Du bom usage du pauvre. Histoire d'un thème politique (XVIe-XXe siècle). [S. 1.]: Fayard, 1990.

Schnapper, D. Intégration et exclusion dans les sociétés modernes. In: Paugan, S. (Dir.). L'exclusion: létat des saviors. Paris: La Découverte, 1996. p. 23-31.

Spozatı, A. Exclusão social e fracasso escolar. Em Aberto, Brasília: INEP, v. 17, n. 71, p. 21-32, jan. 2000. Disponível em: <http://emaberto.inep.gov.br/index.php/emaberto/ article/viewFile/1071/973>. Acesso em: 8 out. 2014.

TÁcito, C. Constituições brasileiras: 1988. 5. ed. Brasília: Senado Federal e Ministério de Ciência e Tecnologia, Centro de Estudos Estratégicos, 2004.v. 7.

Thomas, H. La production des exclus: politiques sociales e processus de désocialisation socio-politique. Paris: Presses Universitaires de France, 1997.

Tourraine, A. Face à l'exclusion. Esprit, Paris: Eurozini, n. 169, p. 7-13, févr. 1991. 
Unicef - Fundo das Nações Unidas para a Infância . O enfrentamento da exclusão escolar no Brasil. Brasília, DF: UNICEF, 2014. Disponível em: <http://www.google. com.br/url $?$ sa $=t \& r c t=j \& q=\& e s r c=s \&$ source $=w e b \& c d=5 \& v e d=0 C D k Q F j A E \& u r l=$ http\%3A\%2F\%2Fwww.foradaescolanaopode.org.br\%2Fdownloads\%2FLivro O_Enfrentamento_da_Exclusao_Escolar_no_Brasil.pdf\&ei=DYmgVOjZHYKoN vi8gaAI\&usg=AFQjCNFh-J5 byQtiKTxcmQMfUqTcb3ZUVw\&bvm=bv.82001339 ,d.eXY>. Acesso em: 10 out. 2014.

Van Zanten, A. Fabrication et effets de la ségrégation scolaire. In: Paugan, S. (Dir.). L'exclusion: l'état des saviors. Paris: La Découverte, 1996. p. 281-291.

\section{SOBRE OS AUTORES}

Alceu Ravanello Ferraro é doutor em ciências sociais pela Pontifícia Universidade Gregoriana (Vaticano). Professor da Universidade Federal do Rio Grande do Sul (UFRGS).

E-mail: alceu.ferraro@pq.cnpq.br

Steven Dutt Ross é doutor em engenharia de produção pela Universidade Federal Fluminense (UFF). Professor da Universidade Federal do Estado do Rio de Janeiro (UNIRIO).

E-mail: steven.ross@uniriotec.br

Recebido em 26 de março de 2015

Aprovado em 8 de setembro de 2015 